\title{
Reforma Izbornog zakonodavstva Bosne i Hercegovine radi ostvarivanja potpune demokracije
}

\author{
Slaven Kovačević \\ Predsjedništvo Bosne i Hercegovine \\ Titova 16, Sarajevo, Bosna i Hercegovine \\ slavenk595@gmail.com
}

\begin{abstract}
Sažetak: Polazeći od ishoda Francuske revolucije iz XVIII stoljeća, kada je došlo do otpora građanstva monarhiji kao formi vladavine, odnosno autokratskim vladarima u to vrijeme, što je dovelo do prelaska na novu formu vladavine - republike - stvoren je novi okvir za ostvarivanje demokratskih prava svih građana kroz njihovo učešće u odlučivanju i donošenju svih zakona u njihovoj zemlji. Nakon proglašenja nezavisnosti i obnove državnosti Bosne i Hercegovine, putem referenduma iz marta 1992. godine, dolazi do tranzicijskog prelaska sa prethodnog socijalističkog sistema na liberalno-demokratski sistem, parlamentarnog karaktera i višestranačje, čime i ova zemlja nastoji postati dijelom demokratskih zemalja. Ustavom Bosne i Hercegovine, koji nije bio izraz demokratske volje građana ove zemlje, iskreiran je jedan novi politički sistem, koji je u svojoj anglo-saksonskoj formi ostavio niz nedorečenosti, koje se i danas reflektiraju na različite oblasti društveno-političkog života, a time i na izborni sistem u zemlji. Nasuprot toga stoje preporuke iz 14 ključnih prioriteta iz Mišljenja Europske komisije o zahtjevu Bosne i Hercegovinu za članstvo u Europskoj uniji, od kojih je jedan reforma izbornog zakonodavstva i uspostavljanje potpune demokracije.
\end{abstract}

Ključne riječi: monarhija, republika, građanska prava, vladavina prava, konsocijacijska demokracija, europski izborni standardi, individualna građanska prava

\section{Deklaracija o ljudskim i građanskim pravima kao temelj potpune građanske demokracije}

Razmatranje bilo kojeg izbornog sistema nije moguće započeti bez uvida u više internacionalnih dokumenata, koji se tiču ili koji se bave ljudskim pravima na individualnom nivou. Odnosno, ako se koncepcijski razmatranje postavi na takav način da je učešće bilo kojeg pojedinca u izborima za različite organe vlasti, jedan od izraza ostvarivanja ljudskih prava i temeljnih sloboda, bez bilo kakvog ograničenja, onda se svakako mora promisliti i o reformi izbornog zakonodavstva Bosne i Hercegovine na istovjetan način. U tom pogledu, svakako je prvi dokument koji o tome govori je Deklaracija o ljudskim i građanskim pravima (izv. Déclaration des droits de l'homme et du citoyen de 
1789) koja je nastala nakon Francuske revolucije iz 1789. godine. Povod za deklaraciju može se sagledati u tome da su tadašnji građani Francuske htjeli izmijeniti sistem vlasti odnosno formu vladavine sa monarhije na republiku, odnosno da se sa monarhističkog sistema vlasti u kojem jedan pojedinac odlučuje sve i umjesto svih, nastojao zamijeniti republičkim sistemom u kojem svi građani podjednako učestvuju u donošenju svih odluka i zakona u svojoj zemlji putem svojih izabranih predstavnika ${ }^{1}$. Kako to kažu Ademović, Marco i Marković: „U biti, republika je vrsta državne vladavine. Suprotna državna forma koja nije republikanska je monarhija. Sadržajno gledajući, državna forma nam govori o tome ko se nalazi na čelu države. U monarhijama na čelu države nalazi se pojedinac - monarh - koji na tu poziciju dolazi nasljeđem ili putem sakralne legitimacije (voljom Boga). U republikama na čelu države nalazi se inokosni ili kolektivni predsjednik, biran direktno ili indirektno, i koji je građanima (naciji) odgovoran politički i pravno. Takva odgovornost $u$ monarhijama ne postoji.“2

Takva inspiracija, u tadašnjem historijskom kontekstu, dovela je do revolucije koja je imala za jedinstven cilj, a to je da se svim građanima omogući ravnopravno učešće $u$ odlučivanju, $u$ njihovoj zemlji, tako što će putem njihovih izabranih političkih predstavnika donositi sve odluke i zakone, koje im država treba vratiti u formi prava. Takav oblik iskazivanja zahtjeva, u prvom koraku prema izabranim predstavnicima u organima vlasti, koji takve zahtjeve koji dolaze ili koje zaprimaju od stvarnog, realnog čovjeka, u drugom koraku artikuliraju prema adekvatnim organima vlasti, koji ih obrađuju i trećem koraku vraćaju prema tom istom čovjeku u okviru prava i ishoda koji je tražen u zahtjevu iz prvog koraka ${ }^{3}$.

Ovdje se može konstatirati, kako je Deklaracija o ljudskim i građanskim pravima, zajedno sa drugim dokumentima, kao što je to Engleska povelja o građanskim pravima iz 1689, zatim američka Povelja o građanskim pravima iz 1789, bila temelj za donošenje Univerzalne povelje o ljudskim pravima Ujedinjenih nacija iz 1948. godine, a nešto kasnije i Europske konvencije o ljudskim pravima i temeljnim slobodama iz 1950. godine. Suština svih pomenutih dokumenata ogleda se u zaštiti prava pojedinca, te da država mora, u okviru principa vladavine prava (eng. Rule Of Law) kao termina iz

\footnotetext{
${ }^{1}$ Sadiković Ćazim: Politički sistemi (treće izmijenjeno i dopunjeno zdanje), Pravni fakultet, Sarajevo (2004), str. 15

${ }^{2}$ Ademović, Marko, Marković: Ustavno pravo Bosne I Hercegovine, Konrad Adenauer Stiftung (2012), str. 87

${ }^{3}$ Sadiković Ćazim: Politički sistemi (treće izmijenjeno i dopunjeno zdanje), Pravni fakultet, Sarajevo (2004), str. 20
} 
anglo-aksonskog prava, obezbijediti jednakost svih pojedinaca pred zakonom bez izuzetaka ili ako se govori o pravnoj državi (ger. Rechtsstadt) gdje se u okviru kontinentalnog prava, između ostalog, govori i o zaštiti jednakosti i prava svih pojedinaca u društvu, što u oba navedena primjera ima isto ishodište koje se odnosi na zaštitu prava građanina, pojedinaca, kako bi se time obezbijedila potpuna pravna sigurnost. Polazeći od takve premise, nameće se logičan zaključak da i u izbornom sistemu, koji se rješava zakonom ili zakonima, svaki pojedinac u svojoj zemlji mora imati istovjetna prava za učešće u izborima, bilo ono aktivno ili pasivno učešće, te da u tom pogledu ne smije biti bilo kakvih ograničenja. Na taj način, dolazi se do takvoga izraza da učešće svih pojedinaca u izbornom sistemu vlastite zemlje, na jednak način i bez izuzetaka bilo koje vrste, stvara ambijent za uspostavljanje potpune demokracije, u kojoj svaki taj pojedinac ravnopravno učestvuje u donošenju svih odluka u svojoj državi, putem svojih političkih predstavnika u organima vlasti, koje taj pojedinac bira na izborima.

\section{Rasprava o elementima političkog sistema u Bosni i Hercegovini}

Sadašnji politički sistem u Bosni i Hercegovini, svoj temelj pronalazi u Ustavu Bosne i Hercegovine, koji je sastavni dio ili Aneks IV Općeg okvirnog sporazuma za mir u Bosni i Hercegovini (Daytonski mirovni sporazum), potpisanog u Daytonu/Parizu 1995. godine. Kako se ne bi zalazilo u prostor ponavljanja različitih činjenica ili čak interpretacija samog ustava, ovdje treba razmotriti samo nekoliko elemenata koji se mogu ticati izbornog sistema u zemlji. Pogledom na preambulu Ustava Bosne i Hercegovine ${ }^{4}$, veoma jasno se može sagledati niz principa na kojima je temeljen ustavni poredak u zemlji, a koji su u međusobnoj zajedničkoj interakciji. Posebno treba voditi računa, da ne postoji zvanični prevod Općeg okvirnog sporazuma za mir u Bosni i Hercegovini, kao ni njegovih 11 aneksa što je potvrdio Ured visokog predstavnika (OHR) kao konačnog tumača civilnog aspekta Daytonskog sporazuma, tako da to dovodi u situaciju da se Ustav Bosne i Hercegovine mora razmatrati onako kako je napisan na engleskom jeziku ${ }^{5}$. Posebno treba voditi računa da je cjelokupan tekst Općeg okvirnog sporazuma za mir u Bosni i Hercegovini pisan terminologijom anglo-saksonskog prava, što u

\footnotetext{
${ }^{4}$ Izvor: http://www.ohr.int/laws-of-bih/constitutions-2/

${ }^{5}$ Izvor: https://www.oslobodjenje.ba/vijesti/bih/ohr-vlasti-bih-su-krive-sto-Daytonski-sporazum-nijepreveden
} 
smislu njegove provedbe u sistemu kontinentalnog prava može prouzrokovati niz teškoća u pravilnom akceptiranju tog sporazuma i svih njegovih aneksa, među kojima je sadržan i Ustav Bosne i Hercegovine, kao Aneks IV.

U prvoj alineji ili stavu Ustava Bosne i Hercegovine, stoji ustavni princip: „Temeljem poštivanja ljudskog digniteta, slobode i jednakosti“ što je moguće osigurati samo na individualnom nivou, iza čega slijedi novi princip u trećoj alineji: „Uvjereni da demokratske institucije vlasti i poštene procedure, $u$ najboljem proizvode miroljubive odnose unutar pluralnog društva" te najzad u osmoj alineji stoji princip: „Inspirisani Univerzalnom Deklaracijom o ljudskim pravima, Međunarodnim paktovima o građanskim i političkim pravima, odnosno o ekonomskim, socijalnim i kulturnim pravima, i Deklaracijom o pravima lica koja pripadaju nacionalnim ili etničkim, vjerskim i jezičkim manjinama, kao i drugim instrumentima ljudskih prava“ iz čega je vidljivo da je ustavno opredjeljenje Bosne i Hercegovine da se zaštite prava svih njenih građana, podjednako i na pojedinačnom nivou.

\section{Osnovni oblik državnog uređenja Bosna i Hercegovine?}

Ipak, da bi se dovoljno precizno razmotrili važniji elementi političkog sistema u Bosni i Hercegovini, potrebno je konstatirati da njenim ustavom nije određen osnovni oblik državnog uređenja, odnosno da li je Bosna i Hercegovina prosta ili složena država, pa još preciznije da li je oblik državnog uređenja unitarni, federalni ili konfederalni. To stvara takav ambijent za različite interpretacije bosanskohercegovačkog oblika državnog uređenja, što dovodi do povišenog zbunjivanja javnosti, bez obzira da li su takve interpretacije tačne ili nisu. Ono što se može ustvrditi, da je praksa u brojnim zemljama takva da u svoje ustave upišu vlastiti oblik državnog uređenja iz kojeg se onda kasnije povlače elementi za uspostavljanje političkog sistema, posebno onog dijela koji se tiče izbora za različite organe vlasti, pa naposljetku i precizno uređeno funkcioniranje organa vlasti u tim državama. Još preciznije, potrebno je reći da Bosna i Hercegovina unutar svoga ustavnog aranžmana, posjeduje određene elemente unitarnog oblika uređenja, jer je ustavom utvrđeno da postoji centralna vlast, koja jedan dio nadležnosti dodjeljuje nižim nivoima vlasti, koji shodno članu III/3b Ustava Bosne i Hercegovine imaju obavezu da se povinuju odredbama Ustava Bosne i Hercegovine. Isto tako, može se konstatirati da Bosna i Hercegovina ima i određene elemente federalnog uređenja jer niži nivoi vlasti, entiteti i kantoni, imaju svoje ustave, zakonodavne, izvršne i sudske organe vlasti, kojima je dodjeljivanje niza njihovih nadležnosti 
ostvareno na takav način da se ovi niži nivoi vlasti mogu vidjeti kao federalne jedinice. Ono što je važno istaći, odnosi se na to da Bosna i Hercegovina nije konfederacija ili zajednica država, jer nju nisu formirale države svojim dogovorom, pa čak ako se pogleda tekst Daytonskog mirovnog sporazuma, vidljivo je da potpisnice sporazuma nisu formirale ovu zemlju, već se dogovorile oko mirovnog rješenja. Ovdje je veoma važno istaći činjenicu iz internacionalnog prava, da mirovne sporazume u pravilu i nikako drugačije, potpisuju učesnice u ratu, što je potvrda da u Bosni i Hercegovini nije bio građanski rat, već međudržavni oružani sukob, onako kako ga utvrđuje u nizu svojih presuda Internacionalni sud za bivšu Jugoslaviju iz Haaga (ICTY).

Pogledom na član I/3 Ustava Bosne i Hercegovine ${ }^{6}$, koji kaže: „Bosna i Hercegovina se sastoji od dva entiteta: Federacije Bosne i Hercegovine i Republike Srpske (u daljnjem tekstu "entiteti")" gdje je akcenat na terminu „,sastoji se od..." (eng. consists of...) a ne da je Bosna i Hercegovina ,sastavljena od..." (eng. comprises of...) kako se to često pogrešno nameće u javnom diskursu, odnosno nju kao državu nisu sastavile neke administrativno-teritorijalne jedinice. To je sasvim dovoljan pokazatelj da ona nije konfederalna država ili državna zajednica. Naravno, nakon arbitražne odluke iz 1999. godine, njenim članom 10. Distrikt Brčko je definiran na sljedeći način: „Konačnom odlukom na prostoru bivše opštine Brčko osnovan je Brčko Distrikt, koji je pod isključivim suverenitetom BiH i kao multietnička, demokratska jedinica lokalne samouprave. ${ }^{67} \mathrm{U}$ formalno-pravnom iskazu ovdje se može konstatirati da se Bosna i Hercegovina sastoji od bh. entiteta Federacija Bosne i Hercegovine, bh. entiteta Republika Srpska i bh. distrikta Brčko.

Razmatrajući tu činjenicu iz internacionalnog prava, da mirovne sporazume potpisuju zemlje, subjekti međunarodnog prava, koje su učesnice u ratu, što onda uvidom u potpisnike Daytonskog mirovnog sporazuma, možemo konstatirati da su učesnice u ratu bile Republika Bosna i Hercegovina, Republika Hrvatska i tadašnja Savezna Republika Jugoslavija, čiji je pravni sljednik današnja Republika Srbija (ovdje treba istaći da je svojevremeno Savezna Republika Jugoslavija izgubila status u Ujedinjenim nacijama koji joj je naknadno vraćen, a da je Republika Srbija, kako ne bi prolazila kroz neizvjesnu proceduru ponovnog prijema u Ujedinjene nacije, svoj status temeljila kao pravni sljednik SR Jugoslavije). Subjekti internacionalnog prava razvrstani su u tri kategorije: suverene zemlje, nadnacionalne organizacije

\footnotetext{
${ }^{6}$ Izvor: http://www.ohr.int/laws-of-bih/constitutions-2/

${ }^{7}$ Ademović, Marko, Marković: Ustavno pravo Bosne I Hercegovine, Konrad Adenauer Stiftung (2012), str. 316
} 
(naprimjer. Ujedinjene nacije, Europska unija itd.) te internacionalne međunarodne organizacije. U tom terminu ,suverene zemlje“ da bi one uopće bile subjekti internacionalnog prava, smatraju se samo zemlje koje posjeduju ova 4 (četiri) elementa: 1. stalno stanovništvo, 2. definiranu teritoriju, 3. vlast i 4. sposobnost da ulaze u međunarodne odnose (što je pridodato nakon Internacionalne konferencije iz Montevidea, 1933. godine) $)^{8}$. I na kraju, ako se nakratko uzme u obzir period nakon Tridesetogodišnjeg rata iz 1648. godine, kada se pojavljuje teorijski okvir za definiranje nositelja suvereniteta, tada se može uvidom u različita ustavna rješenja, na primjeru zemalja okruženja, sagledati da je građanin definiran kao nositelj suvereniteta, koji je neprenosiv, neotuđiv i nepoklonjiv (pogledati Ustav Crne Gore ili Ustav Sjeverne Makedonije, članove 1. i 2.).

Svi ovi elementi jasno ukazuju, da kroz nedostatak uređenosti u Ustavu Bosne i Hercegovine, u onom dijelu gdje je bilo potrebno utvrditi osnovni oblik državnog uređenja, postoji određeni temelj za izazivanje opće zbunjenosti u javnosti, koje eskaliraju do velikog broja različitih interpretacija, a posebno i do kontinuiranog zaobilaženja kod političkih elita upravo toga nedostatka da ustav ne sadrži izraz o tome ko je nositelj suvereniteta, što opet dovodi do špekulacija da su to isključivo ,konstituentni narodi“ što naravno nije tačno. Takvu tezu iznose oni koji temelj nalaze o idejama Jean Jacques Rousseaua, iz njegovog djela „Društveni dogovor“ (izv. Du contrat social; ou Principes du droit politique) iz 1762. godine, u kojem kao kritiku monarhije ili takvog sistema vlasti, kao bolje rješenje nudi ideju da su ljudi nositelji suvereniteta jedne zemlje, koji imaju puno pravo vladati svojom zemljom. Ovdje se, kao i nizu drugih prilika, kod pojedinih interpretatora radi o pogrešno shvaćenom ili prevedenom engleskom terminu ,people“ koji u svome temelju znači ljudi ili kako je to iskazano na francuskom jeziku ,personnes“ ili ,individue“ koji svi zajedno tvore narod svoje zemlje.

\section{Forma vlasti ili vladavine u Bosni Hercegovini}

Koja je forma vlasti ili vladavine u Bosni i Hercegovini, veoma je važno pitanje. Kako je ranije rečeno, postoje dvije forme vladavine, koje daju odgovor na pitanje ko vlada pojedinom državom - da li je to monarh, pojedinac, individua, koji vlast stiče nasljeđem ili državom vladaju svi građani tako što biraju svoje predstavnike u vlast na slobodnim demokratskim izborima. Polazeći od

\footnotetext{
${ }^{8}$ Malanczuk Peter: Modern Introduction to International Law, Seventh Revised Edition, Routhledge (1997), str. 75
} 
činjenice da Bosna i Hercegovina nije monarhija, odnosno samim tim što ona nije monarhija, to znači da ona pripada onom dijelu zemalja koje imaju republičku formu vladavine i da nije obligatorno sadržavati u imenu zemlje termin „republika“ ili u njenim ustavnim odredbama9. Dakle, Bosna i Hercegovina je po formi vladavine republika. Polazeći od takve pretpostavke, radi razmatranja moguće reforme izbornog zakonodavstva, onda je ulazni podatak veoma važan - svi građani Bosne i Hercegovine trebaju imati mogućnost da bez bilo kakvog ograničenja učestvuju u donošenju svih odluka i zakona u svojoj zemlji, putem svojih političkih predstavnika, koje biraju na periodičnim izborima. Izvjesno je kako ima onih političkih aktera, koji nastoje da etničke zajednice, koje oni nazivaju „konstituentnim narodima“ biraju svoje političke predstavnike, čime bi demokracija u Bosni i Hercegovini bila limitirana, ograničena ili nepotpuna. Takvi u svojoj argumentaciji negiraju da ova zemlja ima republičku formu vladavine i to na jedan neodrživ način, tako što ističu da u imenu države Bosne i Hercegovine više ne postoji imenica „Republika“ što je za njih sasvim dovoljan argument da traže neki drugi oblik demokracije u zemlji. Takav pristup, koji je izrazito političke naravi, teško može imati svoje uporište u savremenim teorijama političkih sistema, tako da bi njegovom eventualnom primjenom, ova zemlja imala takav politički sistem, neviđen $u$ praksi drugih zemalja, posebno onih iz Europske unije, što bi ga svrstalo u domen incidentnog političkog sistema.

\section{Konsocijacijska demokracija i Bosna i Hercegovina}

Najzad, postoje i oni koji smatraju kako Bosna i Hercegovina sadrži određeni oblik konsocijacijske demokracije, onako kako je to krajem 1960-ih i početkom 1970-ih razmatrao tvorac ovoga političkog modela Arend Lijphart. Njegova pretpostavka, da se konsocijacijska demokracija primjenjuje u državama u kojima je prisutno duboko segmentirano ili podijeljeno društvo, sa ciljem prevazilaženja mogućih blokada u vršenju vlasti, ili kako kaže sam Lijphart: ,...možda je teško, ali ne i nemoguće, ostvariti i održavati stabilnu demokratsku vladavinu u pluralnim društvima. “10

\footnotetext{
${ }^{9}$ Ademović, Marko, Marković: Ustavno pravo Bosne I Hercegovine, Konrad Adenauer Stiftung (2012), str. 88

${ }^{10}$ Lijphart, Arend: Democracy in Plural Societies - a comparative exploration, Yale University Press (1977), str. 1
} 
Da bi tako nešto bilo moguće, po Lijphartu, potrebno je obezbijediti četiri principa konsocijacijske demokracije ${ }^{11}$ : 1. velika koalicija (eng. Grand Coalition), 2. obostrani ili uzajamni veto, 3. proporcionalna zastupljenost i 4. visok stepen autonomije za različite segmente društva ili autonomija segmenata. Inspiracija za Lijphartov model konsocijacijske demokracije može se pronaći u njegovoj tvrdnji da je potrebno obezbijediti stabilnu demokraciju $\mathrm{i}$ to u onim društvima koja su segmentirana i duboko podijeljena. On svoje ideje argumentira kroz razmatranje elemenata političkih sistema u Belgiji, Holandiji, Švicarskoj, Austriji i jednom broju afričkih i azijskih zemalja.

Međutim, da bi se uopće moglo što podrobnije razumjeti njegove ideje, potrebno je postaviti pitanje - kome je zapravo konsocijacijska demokracija namijenjena? Uvidom u sadržaj Lijphartove knjige „Democracy in Plural Societies - a comparative exploration“ onda je vidljivo da se ona većim dijelom odnosi na zemlje koje su bile pod kolonijalnom vlašću ili upravom europskih zemalja, koje su napuštale svoje kolonije tokom druge polovine XX stoljeća, ali su istovremeno htjele i nastojale zadržati što je veći stepen vlasti i uprave, u ambijentu gdje je brojnost pripadnika koji dolaze iz kolonizatorskih zemalja uvijek i u pravilu bila mnogo manja od brojnosti lokalnog stanovništva. Citirajući Jürga Steinera, Lijphart tvrdi: „,...svaki utjecaj grupa je u proporciji sa njihovom brojčanom snagom“12 i time, zapravo, nastojeći ponuditi određeni model u sistemu odlučivanja, on svjesno ulazi u prostor statističkog izračuna veličine svakog segmenta unutar Velike koalicije, dajući mu onoliku snagu koja proizlazi iz njegove proporcionalnosti koja se izračunava kroz brojčani prikaz u odnosu na cjelokupnu populaciju. Kako su pojedine društvene grupe, koje su u fokusu Lijphartovog razmatranja, relativno male ili manje od ostalih društvenih grupa između kojih postoji određeni antagonizam, bio on političke, kulturološke, tradicijske ili historijske naravi, onda on poseže za tvrdnjom da se radi o segmentiranim ili duboko podijeljenim društvima, čiji nesklad u političkom smislu može dovesti do nestabilne demokracije, pa kao rješenje nudi model konsocijacijske demokracije, kojim bi se primirile silnice koje vrše destabiliziranje demokratskog poretka. Odbranu tih, manjih društvenih grupa, on vidi kroz stvaranje velikih koalicija, u kojima sve društvene grupe imaju pravo uzajamnog veta, koji može značiti i blokadu u vršenju vlasti, ali da će se, kako sam Lijphart kaže, kroz kontinuirano

\footnotetext{
${ }^{11}$ Lijphart, Arend: Democracy in Plural Societies - a comparative exploration, Yale University Press (1977), str. 25

${ }^{12}$ Steiner, Jürg: The Principles of Majority and Proportionality, British Journal of Political Science, broj 1, (1971), str. 63
} 
posezanje veta, zapravo, izgubiti sam smisao veta. Da bi podjela vlasti bila poštena, što bi trebalo smiriti eventualne tenzije, antagonizme i blokade između društvenih grupa ili zajednica, Lijphart nudi proporcionalnu zastupljenost u svim organima vlasti, agencijama, policijskim i sudskim tijelima i tako redom. Kako ovaj model uspostavljanja vlasti nije dao očekivane rezultate, Lijphart iz njega izlazi tvrdnjom da su pojedine zemlje sa konsocijacijskim modelom postupno prelazile na potpunu demokraciju: „,...ne kao razlog neuspjeha konsocijacijske demokracije, već da je konsocijacija radi svog velikog uspjeha učinila sebe suvišnom. “" ${ }^{13}$ Naravno, ovo se može osporiti sa više argumenata, od kojih bi veoma značajan bio taj da konsocijacijska demokracija ne daje prostor za potpunu demokraciju, sadrži najmanje dva elementa koji su u sukobu sa njom, kao što su uzajamni veto i proporcionalna zastupljenost.

Ako bi ovaj model, a neki to povremeno žele, bio primjenjen u Bosni i Hercegovini, onda je potrebno razmotriti dva važna elementa: prvi, da li je Bosna i Hercegovina segmentirano i duboko podijeljeno društvo i drugi, kako bi izgledalo vršenje vlasti, ako bi se primijenila konsocijacijska demokracija. Uvidom u različita historijska razdoblja Bosne i Hercegovine, odnosno da se, za potrebe ovoga rada, iskoriste četiri historijski vidljiva perioda: Bosna i Hercegovina u doba kraljevine Bosne, zatim Bosna i Hercegovina pod Otomanskom upravom, pa Bosna i Hercegovina pod Austro-ugarskom upravom i najzad Bosna i Hercegovina unutar socijalističkog sistema nekadašnje Socijalističke Federativne Republike Jugoslavije (SFRJ), neće biti lako ili skoro nemoguće je pronaći elemente segmentiranog ili duboko podijeljenog društva u bilo kojem od četiri ponuđena razdoblja. Iako se radi o različitim historijskim kontekstima, u nekoliko vremenskih razdoblja, koji samo u prelaznim periodima imaju dodir jedan sa drugim, očito je da bi krajnja podjela mogla biti na one iz imućnijih grupacija, naprimjer velikaši ili feudalci u prva tri razdoblja nasuprot kmetova ili manje imućnih građana, dok je u socijalističkim sistemu, na sličan način postojala razlika između političkih aktera, koji su vidno bilo imućniji od ostatka građana. Ali da se radilo o segmentiranom ili podijeljenom društvu, svakako nije. Podjela društvenih grupacija i njihovo producirano segmentiranje, započinje početkom 1990-ih i agresijom na Bosnu i Hercegovinu, sa istoka i sa zapada, pa nakon potpisivanja Općeg okvirnog sporazuma za mir u Bosni i Hercegovini, tadašnje aktivne politike radile su veoma predano na stvaranju privida o segmentiranom ili dubokom podijeljenom društvu njegovih etničkih zajednica. Ono što treba propitivati,

${ }^{13}$ Lijphart, Arend: Democracy in Plural Societies - a comparative exploration, Yale University Press (1977), str. 2 
odnosi se na to da bosanskohercegovačko društvo, izvjesno, nije podijeljeno tako i u tolikoj mjeri kako ga aktivne politike i politički akteri žele predstaviti kroz političke forme djelovanja koje su temeljene na etničkim politikama ili politikama koje u fokusu, primarno, imaju etničke zajednice. Njihovo obavljanje političkog posla, vrši se kroz potpunu simplifikaciju političkog poretka, da ovdje postoje tri etničke zajednice, koje imaju svoje etničke lidere $i$ koje se između sebe nastoje dogovarati. Takav sistem u svome jezgru sadrži izraz totalitarnih režima, u kojima jedan nepobitan i najčešće samoproglašeni politički lider vrši vlast i donosi odluke u ime svih ostalih pripadnika svoje etničke zajednice. Kao kontra-argument toj tvrdnji, treba postaviti sljedeće pitanje - kako bi izgledala politička slika u Bosni i Hercegovini kada ne bi bilo tih etnički utemeljenih političkih stranaka, odnosno ko bi bio taj koji bi stvarao privid segmentiranog i duboko podijeljenog društva? Izvjesno, takvih zagovornika podijeljenog društva, onda i ne bi bilo. Ono što postoji u javnom diskursu, kako to kaže Haverić, kada govori o zagovornicima konsocijacijske demokracije da se mora prihvatiti njihova deskripcija ,...bosanskohercegovačkog društva, ne kao heterogenog već vijekovima etnički, vjerski i nacionalno podijeljenog, odričući im pravo da preopisivanjem (redeskripcijom) istu situaciju predstave u drugim kategorijama i iznesu drukčije prijedloge." ${ }^{\text {14 }}$ To samo dodatno potvrđuje da oni koji zagovaraju konsocijacijsku demokraciju, postavljaju aksiom da je Bosna i Hercegovina segmentirano i podijeljeno društvo kroz svoju historiju, ne dajući bilo kome da drugačijim argumentima odbaci takve njihove tvrdnje.

Kada bi se ušlo u razmatranje konsocijacijske demokracije u Bosni i Hercegovini, onda bi taj treći princip koji govori o proporcionalnoj zastupljenosti imao veliki utjecaj na izborne procedure, a nakon njih i na formiranje vlasti. Naprimjer, Bosna i Hercegovina ima zakonodavni organ vlasti koji se sastoji od dva doma, donjeg i gornjeg, odnosno Zastupničkog doma i Doma naroda, koji imaju istovjetnu zakonodavnu ulogu, s tim da Dom naroda ima dodatnu snagu kroz instrument ,zaštite vitalnog nacionalnog interesa“ što mu daje veći politički potencijal. Taj Dom naroda Bosne i Hercegovine, sastoji se od 15 zastupnika i to pet Bošnjaka, pet Hrvata i pet Srba, koji su organizirani u Klubove naroda. Primjenom trećeg principa konsocijacijske demokracije, kroz proporcionalnu zastupljenost u odnosu na cjelokupnu populaciju, koristeći elemente posljednjeg popisa stanovništva, onda bi etnički sastav Doma naroda izvjesno bio: osam Bošnjaka (50.1\%), dva Hrvata

\footnotetext{
${ }^{14}$ Haverić, Tarik: Muke sa Liberalizmom, časopis Status, broj 13, (2008), str. 134
} 
(15.4\%) i pet Srba (30.8\%), čime bi se značajno promijenilo odlučivanje u samom gornjem domu. Ista stvar, odnosi se i na Dom naroda Federacije Bosne i Hercegovine, koji trenutno ima 58 zastupnika i to 17 Bošnjaka, 17 Hrvata, 17 Srba i 7 Ostalih. Opet, ako se primijeni treći princip konsocijacijske demokracije o proporcionalnoj zastupljenosti, tada bi naprimjer raspored bio sljedeći: 41 Bošnjak (70.4\%), 13 Hrvata (22.4\%), 1 Srbin (2.5\%) i 3 Ostalih (4.6\%). Ako se ukratko razmotri odluka Ustavnog suda Bosne i Hercegovine, broj U23/14 u predmetu „Božo Ljubić“ kojom se samo djelomično prihvata zahtjev apelanta u dijelu koji se tiče izbora za Dom naroda Federacija Bosne i Hercegovine, dok se drugi dio zahtjeva koji se ticao izbora članova Predsjedništva Bosne i Hercegovine odbacio, ${ }^{15}$ onda ova odluka postaje interesantna iz više razloga. Jedan od važnijih je da ona poništava mali dio odredbi iz Izbornog zakona Bosne i Hercegovine, odnosno sistem izbora zastupnika u Dom naroda Federacije Bosne i Hercegovine koji se delegiraju iz kantona u određenoj proporciji. Zahtjev Ljubića, bio je dijelom naslonjen na ideje konsocijacijske demokracije, jer se tražilo proporcionalno popunjavanje Doma naroda Federacije Bosne i Hercegovine, ali na način da iz onih kantona u kojima su po statističkom prikazu većinske određene etničke zajednice, samo one delegiraju pripadnike svoje etničke zajednice u Dom naroda iz tih željenih kantona, a da u onim kantonima gdje su one dijelom statističke manjine, nema mogućnosti uopće delegiranja pripadnika te manjinske etničke zajednice. To bi bila konsocijacijska demokracija u pokušaju, jer ona u svome trećem principu proporcionalne zastupljenosti, jasno govori da se radi o proporciji društvene grupe ali u odnosu na cjelokupno stanovništvo ili cjelokupnu populaciju jedne zemlje, a ne o odnosu na njene dijelove, što nije isto onome što je apelant Ljubić tražio.

Ako se razmotri i taj konsocijacijski princip uzajamnog veta, za kojeg Lijphart tvrdi da će postepeno nestajati i to onda kada politički lideri kroz kontinuirano korištenje veta, treba da samostalno shvate da je on nepotreban i da će njegovo korištenje, jednostavno, samo po sebi nestati, postaje jasno da je to u potpunoj suprotnosti sa aktualnim političkim zbivanjima u Bosni i Hercegovini, na način da politički lideri etničkih političkih stranaka veoma rado posežu za vetom (,zaštitom vitalnog nacionalnog interesa“) kako bi time sebi i svojim politikama dali veći potencijal (najčešće kroz međusobne političke ucjene) nego što bi im u demokratskim društvima pripadao. U Bosni i Hercegovini, taj instrument veta, koji se naziva ,zaštita entitetskog interesa“

\footnotetext{
${ }^{15}$ Odluka Ustavnog suda U23/14 po zahtjevu Bože Ljubića (2016)
} 
ako se pokreće preko pojedinog člana Predsjedništva Bosne i Hercegovine ili „zaštita vitalnog nacionalnog interesa“ ako se pokreće u domovima naroda, zapravo je instrument stalnih blokada rada državnih institucija, sa osnovnom idejom da se preko njega, metodom političke ucjene, realiziraju partikularni politički ciljevi. Zasigurno, njegovo neprekidno korištenje ne bi dovelo do obesmišljavanja veta, već naprotiv, njegovo bi korištenje, od onih političkih grupacija koji imaju manji politički kapacitet u apsolutnom broju zastupnika u odnosu na druge grupacije, davalo mogućnost da imaju veći politički potencijal nego što bi im u ambijentu potpune demokracije pripadao. To bi takvim političkim akterima bila stalna inspiracija, da što više pokreću veto, kako bi na taj način stvarali privid da imaju veći politički potencijal od onoga koji bi im trebao, realno, pripadati u ambijentu potpune demokracije.

Dodatno tome, potrebno je ukazati da politički ambijent u kojem samozvani lideri etničkih zajednica imaju mogućnost da odlučuju o svemu, direktno ili preko njima lojalnih kadrova iz etničkih političkih stranaka, vidljivo sadrži elemente totalitarnih sistema, koji skoro da nemaju direktnu vezu sa demokracijom, posebno ako imamo u vidu da njima izbori služe da izaberu, postave ili imenuju samo one kadrove koji će ih bespogovorno slušati. Ovdje je važno istaći da se u totalitarnim sistemima ne vodi računa o zaštiti individualnih građanskih, ljudskih prava, pa se na sličan način politički akteri iz domena etničkih političkih stranaka u Bosni i Hercegovini odnose i prema građaninu ili pojedincu, nastojeći umanjiti njihova individualna ljudska prava i podrediti ih pravima kolektiviteta ili etničkih zajednica koje nazivaju konstituentnim narodima. To, također, nije izraz potpune demokracije.

Zato možemo ustvrditi da Bosna i Hercegovina ne sadrži elemente konsocijacijske demokracije, te da bi eventualan prelazak na takav politički model imao poteškoće u ispunjavanju kriterija za članstvo u nadnacionalnim organizacijama kao što su to Europska unija i NATO savez.

\section{Reforma izbornog sistema Bosne i Hercegovine}

Rasprava o izbornom sistemu u Bosni i Hercegovini, treba započeti sa odgovorom na tri pitanja - ko se bira u organe vlasti, kako se bira i ko bira na izborima. Kada se ta pitanja razmotre u dovoljnoj mjeri i uporede sa europskim vrijednostima i izbornim normama, pa se tome dodaju i pet presuda Europskog suda za ljudska prava iz Strasbourga u predmetima Sjedić-Finci, Zornić, Pilav, Šlaku i Pudarić, onda se stvara dovoljan temelj za uspostavljanje određene teze o tome kako bi se trebao reformirati sadašnji izborni sistem. 
Izbori u Bosni i Hercegovini, kao i u velikom broju drugih zemalja, dešavaju su u frekventnim periodima od četiri godine i imaju svoj naziv Opći izvori, dok se na polovini mandatnog perioda organiziraju i Lokalni izbori ili izbori za jedinice lokalne samouprave. Opći izbori izazivaju ponajviše nedoumica i reforma izbornog zakonodavstva bi se trebala odnositi na njih iz dva razloga - prvi jer je sadašnji sistem Općih izbora osporen u pet presuda Europskog suda za ljudska prava i drugi, jer u Mišljenju Europske komisije o zahtjevu Bosne i Hercegovine za članstvo u Europskoj uniji, eksplicitno se unutar 14 ključnih prioriteta traži izmjena izbornog zakonodavstva u skladu sa europskim standardima i mišljenjem ODIHR-a (Ured OSCE-a za demokratske institucije i ljudska prava). Opći izbori sadrže izbore: za članove Predsjedništva Bosne i Hercegovine; zatim za zastupnike u državni parlament koji se biraju neposredno, ali se zastupnici za Dom naroda biraju posredno iz entitetskih parlamenata; zastupnici za entitetske parlamente biraju se neposrednim izborima, a za domove ili vijeća naroda posredno; u jednom od bh. entiteta Republika Srpska, biraju se predsjednik i potpredsjednici entiteta direktno na izborima, u drugom bh. entitetu Federacija Bosne i Hercegovine, predsjednik i potpredsjednici se biraju posredno; i na kraju neposredno se biraju zastupnici u kantonalnim skupštinama. K tome, Opći izbori se odvijaju u posebno definiranim izbornim jedinicama, čiji broj zavisi od nivoa vlasti i za svaki od njih je različit.

U skladu sa Ustavom Bosne i Hercegovine, u Predsjedništvo Bosne i Hercegovine biraju se tri člana i to dva iz bh. entiteta Federacije Bosne i Hercegovine, Bošnjak i Hrvat i jedan iz bh. entiteta Republika Srpska i to Srbin. Ovo prikazuje kako postoje ograničenja u izboru za članove Predsjedništva Bosne i Hercegovine, i to najmanje dva - prvi da je izbor isključivo ograničen na pripadnike etničkih zajednica koji se ovdje nazivaju konstituentnim narodima i drugi da se oni moraju birati isključivo iz dva bh. entiteta. Kada bi se propitivalo, a često se i propituje, koga članovi Predsjedništva Bosne i Hercegovine predstavljaju, odgovor bi bio jednostavan da kao kolektivni organ mogu predstavljati samo sve građane Bosne i Hercegovine, iako je njihov izbor temeljen na etničkoj pripadnosti i teritoriji entiteta iz kojeg dolaze.

Što se tiče izbora u zakonodavne organe vlasti, odnosno parlamente, državne, entitetske i kantonalne, njihov izbor je vezan za izborne jedinice gdje se svaki građanin može kandidirati, ali onda imamo poteškoću oko izbora rukovodstava tih parlamenata, koji je temeljen isključivo na pripadnosti nekom od konstituentnih naroda. Sličnu situaciju imamo i sa zastupnicima u domovima ili vijećima naroda. 
Za razmatranje ovakvog sistema izbora potrebno se, ukratko, osvrnuti na jedan dio filozofije iz Platonovog djela „Republika“ kroz interpretaciju Francisa Fukuyame, koji govori o podjeli ljudske duše na tri dijela, gdje taj treći dio pod nazivom „Thymos“ koji nema direktan prijevod sa starog grčkog jezika, te posjeduje zahtjev svakog čovjeka da bude priznat od drugog ljudskog bića na jednaki način. Fukuyama kaže da se: „...nejednako priznanje gospodara i robova zamjenjuje univerzalnim i uzajamnim priznavanjem, gdje svaki građanin prepoznaje dostojanstvo i humanost svakog drugog građanina, a gdje to dostojanstvo država priznaje zauzvrat davanjem prava." ${ }^{\text {"16 }}$ U tome, može se pridružiti dodatni iskaz da se Thymos dijeli na dva dijela megalothymiju i isothymiju. ${ }^{17}$ Megalothymia sadrži potrebu ljudskog bića da bude priznato i prihvaćeno kao superiornije u odnosu na druga bića, dok sa druge strane isothymia traži međusobno priznanje svih ljudskih bića na ravnopravan način. U svome radu „Protiv politike identiteta“ Fukuyama zaključuje: „Uspon moderne demokracije priča je o trijumfu isothymije nad megalothymijom: društva koja su priznala prava samo malog broja elita trebaju biti zamijenjena sa onima koja su sve pojedince prepoznala kao međusobno jednake. ${ }^{\text {"18 }} \mathrm{U}$ tome domenu, potrebno je razmatrati i današnju tendenciju za reformom izbornog sistema Bosne Hercegovine. Tome se mora pridodati i formalni zahtjev Europskog suda za ljudska prava iz Strasbourga u svih opet predmeta: Sejdić-Finci, Zornić, Pilav, Šlaku i Pudarić, kojima je osporen izbor za članove Predsjedništva Bosne i Hercegovine, kao i za zakonodavne organe vlasti, jer su domaći izbori temeljeni isključivo na etničkoj pripadnosti onih koji se svrstavaju u konstituentne narode, a k tome i da imaju različita prava u odnosu na mjesto prebivališta. U presudi Sejdić-Finci, u tački 43. kada se govori o diskriminaciji na etničkoj osnovi se kaže: „Diskriminacija po osnovu etničkog porijekla nekog lica predstavlja jedan od oblika rasne diskriminacije (vidjeti definiciju koju je usvojila Međunarodna konvencija o ukidanju svih oblika rasne diskriminacije u tački 19. u tekstu i onu koju je usvojila Evropska komisija za borbu protiv rasizma i netolerancije u tački 23. u tekstu). Rasna diskriminacija je posebno okrutan oblik diskriminacije i, s obzirom na njene opasne posljedice, traži od vlasti poseban oprez i odlučne reakcije. “19 Ako se pogleda i član 19. na koji se tačka 43. referira, onda se može vidjeti sljedeći iskaz: „Međunarodna konvencija o ukidanju svih oblika

\footnotetext{
${ }^{16}$ Fukuyama, Francis:, The End of History and the Last Man, Free Press, New York (2006), str. xvi-xvii ${ }^{17}$ Ibid, str. 182

${ }^{18}$ Fukuyama, Francis, Against Identity Politics, časopis Foreign Affairs, broj: avgust 2018

${ }^{19}$ Presuda Europskog suda za ljudska prava iz Strasbourga u predmetu „Sejdić-Finci protiv Bosne i Hercegovine“" broj 27996/06 i 34836/06, (2009), str. 31
} 
rasne diskriminacije, usvojena pod okriljem Ujedinjenih naroda 21. decembra 1965., stupila je na snagu u odnosu na Bosnu i Hercegovinu 16. jula 1993. Relevantni dio člana 1. ove Konvencije glasi: U ovoj konvenciji izraz 'rasna diskriminacija' odnosi se na svako razlikovanje, isključivanje, ograničavanje ili davanje prvenstva koji se zasnivaju na rasi, boji, precima, nacionalnom ili etničkom porijeklu koji imaju za svrhu ili za rezultat da naruše ili da kompromitiraju priznavanje, uživanje ili ostvarenje, pod jednakim uslovima, prava čovjeka i osnovnih sloboda na političkom, ekonomskom, socijalnom i kulturnom polju ili u svakoj drugoj oblasti javnog života. “20

Ovaj iskaz iz predmeta „Sejdić-Finci protiv Bosne i Hercegovine“ još je jedna od potvrda da u bosanskohercegovačkom ustavnom sistemu postoji diskriminacija značajnog dijela građana, koja je utemeljena na etničkoj pripadnosti i koju Evropski sud za ljudska prava iz Strasbourga, koristeći relevantne odredbe međunarodnih konvencija, smatra oblikom rasne diskriminacije. Ovim zahtjevom imperativne prirode, navedenim u predmetu „Sejdić-Finci“ Europski sud za ljudska prava svojom presudom naložio je Bosni i Hercegovini (a ne da se o tome pregovara i razgovara), da svi građani moraju imati pravo kandidiranja za Predsjedništvo Bosne i Hercegovine, te da se u Parlamentarnoj skupštini Bosne i Hercegovine, u Domu naroda treba uvesti i Klub Ostalih. Ovo, na prvi pogled izgleda interesantno i korisno, ali implementiranjem samo presude „Sejdić-Finci“ riješilo bi se premalo toga, odnosno postojanje sistemske diskriminacije ne bi bilo u cjelosti ukinuto, već bi ono bilo ostavljeno i to tako što bi u tome učešće imale tri etničke zajednice, koje se nazivaju „konstituentnim narodima“ ali bi im se pridodali, kao posebna grupacija, onaj dio građana koje Ustav Bosne i Hercegovine vidi kao pripadnike Ostalih. To svakako ne bi bilo potpuno rješenje niti potpuna demokracija.

Ipak, ono što je mnogo važnije, sadržano je u predmetu ,Zornić protiv Bosne i Hercegovine“ gdje aplikantica, gospođa Azra Zornić, u svojoj apelaciji kaže: „Kako se aplikantica ne izjašnjava kao pripadnica nijednog od „konstituentnih naroda“ (odnosno, Bošnjaka, Hrvata i Srba), nego jednostavno kao građanka Bosne i Hercegovine, ona ne može biti kandidat na izborima za drugi dom državnog parlamenta (Dom naroda), kao ni za kolektivnog šefa države (Predsjedništvo).“21 Dodatno se kaže: „Aplikantica tvrdi da joj, unatoč tome što je državljanka Bosne i Hercegovine, Ustav uskraćuje pravo

\footnotetext{
${ }^{20}$ Ibid. str. 13

${ }^{21}$ Presuda Europskog suda za ljudska prava iz Strasbourga u predmetu „Zornić protiv Bosne i Hercegovine“" broj 3681/06, (2014), str. 2
} 
da se kandidira na izborima za Dom naroda i Predsjedništvo budući da se ne izjašnjava kao pripadnica jednog od „konstituentnih naroda“, niti bilo koje etničke skupine.“22 Dakle, ovdje je takav slučaj, kada se jedno lice pojavljuje na način da ne želi da se izjasni kao pripadnik jednog od konstituentnih naroda, niti se izjašnjava kao pripadnica Ostalih, već jednostavno kao građanka ove zemlje, ona nema pravo kandidiranja za pojedine zakonodavne i izvršne organe vlasti. Gospođa Zornić, referira se u svojoj apelaciji i na presudu „SejdićFinci“" u kojoj je već bilo utvrđeno postojanje diskriminacije u Ustavu Bosne i Hercegovine, te traži da Sud naloži ispravljanje takvih nedostataka u samom ustavu, pozivajući se na član 46. Europske konvencije o zaštiti ljudskih prava i temeljnih sloboda, u kojem izričito stoji: „1. Visoke strane ugovornice obavezuju se da će se povinovati konačnim presudama Suda u svakom predmetu u kojem su strana u postupku. i 2. Konačna presuda Suda dostavlja se Komitetu ministara koji će vršiti nadzor nad njenim izvršenjem." ${ }^{23}$ To znači, kako je Bosna i Hercegovina, koja je pristupila Vijeću Europe 2002. godine, te iste godine ratificirala Europsku konvenciju o ljudskim pravima i temeljnim slobodama, prihvatila nadležnost Europskog suda za ljudska prava i obavezala se na provođenje njegovih presuda. Slična odredba postoji i u članu II/2 Ustava Bosne i Hercegovine u kojem se utvrđuje obaveza da: „Prava i slobode predviđeni u Evropskoj konvenciji za zaštitu ljudskih prava i osnovnih sloboda i u njenim protokolima se direktno primjenjuju u Bosni i Hercegovini. Ovi akti imaju prioritet nad svim ostalim pravima.“”

$\mathrm{Na}$ temelju toga, veoma je interesantno sagledati šta je to Europski sud za ljudska prava iz Strasbourga, utvrdio u članu 43. presude u predmetu „Zornić“ i šta je sve naložio državi Bosni i Hercegovini, kao Visokoj strani ugovornici: „U presudi Sejdić i Finci Sud je primijetio da je u vrijeme kada su donesene sporne ustavne odredbe na terenu došlo do vrlo krhkog primirja, te da je cilj tih odredbi bio da se zaustavi brutalni sukob obilježen genocidom i ,etničkim čišćenjem“ (vidi ibid., tačka 45). Priroda tog sukoba bila je takva da je bilo neophodno pristati na „konstituentne narode” kako bi se osigurao mir (ibid.). Međutim sada, više od osamnaest godina nakon završetka tragičnog sukoba, ne može postojati bilo kakav razlog za održavanje na snazi spornih ustavnih odredbi. Sud očekuje da će se bez daljeg odgađanja uspostaviti demokratsko uređenje. S obzirom na potrebu da se osigura stvarna politička demokracija, Sud smatra da je došlo vrijeme za politički sistem koji će svakom građaninu Bosne i Hercegovine osigurati pravo da se kandidira na izborima za

\footnotetext{
${ }^{22}$ Ibid. str. 7

${ }^{23}$ Europska konvencija o ljudskim pravima i temeljnim slobodama, str. 24
} 
Predsjedništvo i Dom naroda Bosne i Hercegovine, bez diskriminacije po osnovu etničke pripadnosti i bez davanja posebnih prava konstituentnim narodima uz isključivanje manjina ili građana Bosne i Hercegovine. “24

Ovdje bi se, ukratko, moglo razmotriti nekoliko važnih elemenata iz pomenutog člana 43. presude Europskog suda za ljudska prava iz Strasbourga u predmetu „Zornić.“ Prvi od njih, ogleda se u tome da su sporne ustavne odredbe donesene u toku trajanja krhkog primirja, te da je cilj takvih odredbi bio da se zaustavi brutalni sukob, koji je obilježen genocidom i etničkim čišćenjem. Pa se dalje kaže da je radi prirode toga sukoba bilo neophodno pristati na „konstituentne narode“ kako bi se osigurao mir. Time je, očito, došlo do narušavanja jednog važnog principa u internacionalnom pravu - Nec vi, nec clam, nec precario - što bi u prijevodu značilo „,bez sile, bez tajnosti, bez saglasnosti“ odnosno ako se pojedini sporazum sklapao na način da u tome ima prisile, ima tajnosti i bez saglasnosti ili dobrovoljnosti, onda su odredbe toga međunarodnog sporazuma ništavne. Tome se treba pridodati i norma „ius cogens“ koja je sadržana u članu 53. Bečke konvencije o ugovornom pravu, koja izričito kaže da je svaki sporazum koji je nastao na genocidu ili dijelovi sporazuma koji imaju utemeljenje u počinjenom genocidu, nemaju bilo kakvu pravnu snagu i trebaju biti poništeni. Ako bi ovo bilo primijenjeno na odredbu 43. iz presude u predmetu „Zornićc onda bi pravna posljedica bila da su odredbe Općeg okvirnog sporazuma za mir u Bosni i Hercegovini, odnosno njegovog Aneksa IV ili Ustava Bosne i Hercegovine, koje su nastale bez dobre volje, pod određenom prisilom, a k tome imajući u vidu da je počinjen genocid i etničko čišćenje, tada je jedini logičan zaključak da dio Aneksa IV koji govori o „konstituentnim narodima“ na koje se moralo pristati kako bi se osigurao mir, ne bi trebao biti važeći. Naravno, ima još elemenata iz Daytonskom sporazumu, koji su sporni sa stanovišta pomenute norme internacionalnog prava, ali kako je predmet ovoga rada reforma izbornog zakonodavstva, njihova dalja elaboracija nije potrebna.

Drugi problem iz presude „Zornić“ odnosi se na nalog Europskog suda za ljudska prava da Bosna i Hercegovina mora obezbjediti potpunu demokraciju, što je rezultat konstatacije da je demokracija ovdje dodjeljena samo „konstituentnim narodima“ ili da je ona ograničena ili limitirana, te da se mora obaviti izmjena ustava na način da će svi građani Bosne i Hercegovine imati jednaka prava unutar političkog sistema, a time i unutar izbornih procedura. Europski sud za ljudska prava iz Strasbourga nalaže Bosni i Hercegovini da

\footnotetext{
${ }^{24}$ Presuda Europskog suda za ljudska prava iz Strasbourga u predmetu „Zornić protiv Bosne i Hercegovine“ broj 3681/06, (2014), str. 11
} 
se uspostavi demokratsko uređenje, što je dodatna potvrda da u ovome trenutku u ovoj zemlji ne postoji potpuno demokratsko uređenje, već ono limitirano na raspodjelu moći između etničkih zajednica.

Stavljajući pomenuto u kontekst sa Mišljenjem Europske komisije o zahtjevu Bosne i Hercegovine za članstvo u Europskoj uniji, gdje se kaže: „Ustav sadrži odredbe zasnovane na etničkoj pripadnosti i prebivalištu koje nisu u skladu sa Europskom konvencijom o ljudskim pravima. To su odredbe koje se odnose na imenovanje, sastav i postupke odlučivanja šefa države i izvršnih i zakonodavnih tijela, budući da su određena izborna prava rezervisana za građane koji pripadaju „konstituentnim narodima“ - Bošnjacima, Hrvatima i Srbima. Stoga su potrebne značajne dodatne reforme kako bi se osiguralo da svi građani mogu ostvarivati svoja politička prava, u skladu sa presudom Europskog suda za ljudska prava (ECtHR) u predmetu SejdićFinci“'25 potvrđuje se, također, da u Bosni i Hercegovini nema potpune demokracije, te se i u Mišljenju Europske komisije traži reforma kako bi svi građani mogli ostvarivati svoja politička prava. Najzad, kao ključni prioritet broj 1. iz Mišljenja Europske komisije kaže se: „Osigurati da se izbori provode u skladu s evropskim standardima tako što će se provesti relevantne preporuke OSCE-a/ODIHR-a i Venecijanske komisije, osigurati transparentnost finansiranja političkih stranaka i održati lokalne izbore u Mostaru. “26

Kada se ovo sublimirano sagleda, onda se kao logičan zaključak nameće da Bosna i Hercegovina treba obaviti reforme, u prvom koraku svoga ustava, kako bi se iz njega izbacile sve sporne odredbe koje sadrže sistemsku diskriminaciju, što očito neće biti nimalo lagan zadatak. Sadašnje političke elite, posebno one koje zagovaraju etničke politike, a među njima samozvani lideri etničkih zajednica, izvjesno su svjesni da bi reforma Ustava Bosne i Hercegovine, koja bi ponudila drugačiji politički sistem temeljen na potpunoj građanskoj demokraciji, u velikoj mjeri smanjila njihovu osobnu političku moć, posebno onu u domenu donošenja odluka i imenovanja političkih kadrova. To bi mogla biti ozbiljna poteškoća za bilo koji vid reformi koji bi ulazio u domen umanjenja političke moći samozvanih lidera etničkih zajednica, jer oni na tako važan iskorak vidno nisu spremni. Zato se sa pravom postavlja pitanje, koliko su oni stvarno zainteresirani za europske standarde koji bi Bosnu i Hercegovinu doveli do kandidatskog statusa za Europsku uniju, a kasnije kroz otvaranje pregovaračkog procesa i čitav niz drugih reformi,

\footnotetext{
${ }^{25}$ Mišljenje Europske komisije o zahtjevu Bosne i Hercegovine za članstvo u Europskoj uniji (2019), str. 6

${ }^{26}$ Ibid. str. 14
} 
koji bi u cijelosti izmijenili politički, ali i ekonomski sistem ove zemlje? Za sada, odgovor je jednostavan i slijedi iz dosadašnjeg ponašanja lidera etničkih političkih stranaka iz kojeg se vidi da oni nisu spremni na bilo kakve reforme koje bi za ishod imale umanjenje sadašnjeg stepena njihove neograničene političke moći.

Nakon što bi, eventualno, Ustav Bosne i Hercegovine bio izmijenjen, tada bi slijedila ozbiljna reforma izbornog zakonodavstva, koje mora biti usklađeno sa europskim standardima. Uvidom u Lisabonski ugovor, koji je trenutni sporazum koji uređuje odnose u Europskoj uniji, odnosno njegov član 6, onda i tamo se može vidjeti, da je ova nadnacionalna organizacija u svoje temelje ugradila poštivanje ljudskih prava i temeljnih sloboda na individualnom nivou. To onda znači, da kada bi došlo do otvaranja pregovaračkih poglavlja za pristupanje Europskoj uniji, stepen reformi koje Bosna i Hercegovina mora obaviti nije mali, ali isto tako, takve reforme moraju početi iz temelja, odnosno u prvom koraku se mora obezbijediti jednakopravnost svih građana, kao jedan od temeljnih principa na kojima počiva politički sistem Europske unije, pa bi tek nakon toga slijedile druge reforme. Tek tada, Bosna i Hercegovina bi imala politički sistem koji sadrži potpunu demokraciju i jednakost svakog njenog stanovnika, koji bi u svome temelju bio usklađen sa traženim europskim standardima.

\section{Zaključak}

Bosna i Hercegovina je nakon potpisivanja Općeg okvirnog sporazuma za mir u Daytonu i Parizu, 1995. godine, dobila novo ustavno uređenje, koje ne sadrži elemente potpune demokracije, što je već osporeno u pet presuda Europskog suda za ljudska prava iz Strasbourga u predmetima Sejdić-Finci, Zornić, Pilav, Šlaku i Pudarić. Polazeći od Fukuyamine teze da liberalna demokracija nastoji biti utemeljena na isothymiji, odnosno potrebi svakog ljudskog bića za jednakim i ravnopravnim priznanjem od drugoga ljudskog bića, te da u tom pogledu isothymia treba nadvladati i pobijediti megalothymiju ili potrebu da se neko osjeća superiornijim u odnosu na onoga drugoga, onda je tako nešto vidljivo i u Bosni i Hercegovini, gdje se pripadnici „konstituentnih naroda“" smatraju iznad onih koji sebe vide „samo građanima“ uz zahtjev da im tako nešto država u kontinuitetu priznaje u formi viših prava za njih. K tome, presude Europskog suda za ljudska prava iz Strasbourga, utvrdile su postojanje diskriminacije u Ustavu Bosne i Hercegovine, upravo na toj tezi da se pripadnicima „konstituentnih naroda“ putem ustava daju viša ili veća prava, što Bosnu 
i Hercegovinu dovodi u stanje nepotpune ili ograničene demokracije. Na istoj liniji je dio iz Mišljenja Europske komisije o zahtjevu Bosne i Hercegovine za članstvo u Europskoj uniji, u kojem se, također, postavlja zahtjev za reformom ustavnog uređenja i političkog sistema, kako bi svi građani ove zemlje imali jednaka prava. Nasuprot toga, u Bosni i Hercegovini egzistiraju političke elite iz domena etničkih politika (iako je teško prihvatiti da se bilo ko smatra elitom, jer to u svome izrazu podrazumijeva da se radi o najboljim od najboljih, što u Bosni i Hercegovini nije slučaj), koji radi vlastitog komfora, povlastica i potrebe da imaju veći stepen prava i političke moći, kroz samozvane lidere etničkih zajednica, nastoje ovakav politički sistem održati što duže, iako bi to u konačnici moglo značiti otežavanje, a kod pojedinih aktera i potpuno odbacivanje euro-atlantskih integracija Bosne i Hercegovine.

Međutim, Bosna i Hercegovina ima potpisan Sporazum o stabilizaciji i pridruživanju (SSP), koji je ,posebna vrsta, odnosno treća generacija sporazuma o pridruživanju koje je Europska unije ponudila isključivo državama Zapadnog Balkana.“27 Ovaj sporazum, Bosna i Hercegovina je potpisala 2008. godine, koji je stupio na snagu 2015. godine, čime se stvara niz formalno-pravnih obaveza za Bosnu i Hercegovinu unutar njenih europskih težnji. Time se Bosna i Hercegovina obavezala na niz reformi, od kojih svakako jedna od njih mora biti izmjena Ustava Bosne i Hercegovine, koji se mora uskladiti sa acquis communautaire ili europskom pravnom stečevinom, kako bi se stvorio pravni osnov za izmjene postojećih i donošenje niza novih zakona, koji će doći kao zahtjev iz Europske unije, nakon obavljenog „screaninga“ ili pregleda usaglašenosti sveukupnoga bosanskohercegovačkog zakonodavstva sa europskom pravnom stečevinom, koji slijedi nakon dodjeljivanja kandidatskog statusa. Jedna od reformi svakako mora biti i izmjena izbornog zakonodavstva, unutar potpune demokracije i jednakopravnosti svih građana ove zemlje. Kada će takve reforme doći na red i ko će ih obaviti, pitanje je koje ima samo dva odgovora: prvi da bi to mogle uraditi sadašnje političke elite i to što prije, kako bi se uhvatio priključak sa drugim zemljama koje su u prednosti unutar europskih integracija ili da se sačeka neka nova generacija političkih aktera koji neće biti uhvaćeni u zamku etničkih politika, već će imati dovoljno sposobnosti i razumijevanja da vide da su europske integracije u korist Bosne i Hercegovine i svih njenih građana.

Polazeći od početne teze da je nakon Francuske revolucije iz XVIII stoljeća, iskazana volja građana da odbace monarhiju i totalitarni sistem, kako

${ }^{27}$ Halilović, Safet: Evropske integracije i Bosna i Hercegovina, Fakultet političkih nauka Sarajevo, (2013), str. 208. 
bi se obezbijedilo republičko uređenje u kojem svi građani mogu učestvovati u donošenju svih odluka i zakona u svojoj zemlji, putem svojih izabranih predstavnika u organima vlasti, onda se kao jedan od zaključaka nameće taj, da Europa ima i živi potpunu demokraciju već nekih 230 godina, dok Bosna i Hercegovina koja postoji skoro hiljadu godina, u posljednjih 25 godina ostaje zarobljena u etničkim politikama, koje u svome korijenu sadrže totalitarni karakter. Zašto je to tako? Izvjesno radi potrebe pojedinih političkih aktera, da kroz pojednostavljenje političkog sistema Bosne i Hercegovine, zadrže ogromnu koncentraciju političke moći, koja im daje prostor za neograničen stepen političkog odlučivanja. Taj jednostavan oblik političkog sistema, temeljen na etničkim politikama, lakši je za konzumaciju kod jednog broja stanovnika ove zemlje, jer se svako razmišljanje svodi na statističko prebrojavanje pripadnika etničkih zajednica, a na taj način i formiranje straha od nekog preglasavanja ili odlučivanja nekih drugih, umjesto onih koji dolaze iz željene etničke zajednice. To svakako nije potpuna demokracija iako je lakša za upotrebu, ali isto tako takav sistem ne vodi Bosnu i Hercegovinu u Europsku uniju i NATO savez. Zato je važno izgraditi povjerenje kod stanovnika ove zemlje da jednakopravnost građana, kroz politički sistem koji bi bio usklađen sa europskim standardima, zapravo bi bio u korist svih, a nikako protiv bilo koga.

\section{Literatura}

Ademović, Marko, Marković: Ustavno pravo Bosne I Hercegovine, Konrad Adenauer Stiftung (2012)

Halilović, Safet: Evropske integracije i Bosna i Hercegovina, Fakultet političkih nauka Sarajevo, (2013)

Lijphart, Arend: Democracy in Plural Societies - a comparative exploration, Yale University Press (1977)

Malanczuk Peter: Modern Introduction to International Law, Seventh Revised Edition, Routhledge (1997)

Sadiković Ćazim: Politički sistemi (treće izmijenjeno i dopunjeno zdanje), Pravni fakultet, Sarajevo (2004)

Steiner, Jürg: The Principles of Majority and Proportionality, British Journal of Political Science, broj 1, (1971)

\section{Izvori}

Europska konvencija o ljudskim pravima i temeljnim slobodama

Fukuyama, Francis, Against Identity Politics, časopis Foreign Affairs, broj: august 2018

Haverić, Tarik: Muke sa Liberalizmom, časopis Status, broj 13, (2008)

Ustav Bosne i Hercegovine, http://www.ohr.int/laws-of-bih/constitutions-2/

Daytonski sporazum nije preveden, https:/www.oslobodjenje.ba/vijesti/bih/ohr-vlasti-bihsu-krive-sto-Daytonski-sporazum-nije-preveden 
Mišljenje Europske komisije o zahtjevu Bosne i Hercegovine za članstvo u Europskoj uniji (2019)

Odluka Ustavnog suda U23/14 po zahtjevu Bože Ljubića (2016)

Presuda Europskog suda za ljudska prava iz Strasbourga u predmetu „Sejdić-Finci protiv Bosne i Hercegovine“ broj 27996/06 i 34836/06, (2009)

Presuda Europskog suda za ljudska prava iz Strasbourga u predmetu „Zornić protiv Bosne i Hercegovine“" broj 3681/06, (2014)

\title{
Reform of the Election Legislation of Bosnia and Herzegovina to Achieve Complete Democracy
}

\begin{abstract}
Summary
Starting from the outcome of the French Revolution of the XVIII century, when there was resistance of citizens to the monarchy as a form of government, or autocratic rulers at the time, which led to the transition to a new form of government - the republic - it created a new framework for democratic rights of all citizens and their participation in decision-making process and the enactment of all laws in their country. After the declaration of independence and the restoration of the statehood of Bosnia and Herzegovina, through a referendum in March 1992, there was a transition from the previous socialist system to the liberal-democratic system, parliamentary character and multi-party system, which makes this country part of democratic countries. The Constitution of Bosnia and Herzegovina, which was not an expression of the democratic will of the citizens of this country, created a new political system, which in its Anglo-Saxon form left a number of ambiguities, which are still reflected in various areas of socio-political life including the electoral system in the country. In contrast, there are recommendations from 14 key priorities from the European Commission's Opinion on Bosnia and Herzegovina's application for membership in the European Union, one of which is the reform of electoral legislation and the establishment of full democracy.
\end{abstract}

Key words: monarchy, republic, civil rights, rule of law, consociational democracy, European electoral standards, individual civil rights 